\title{
PENINGKATAN DAYA SAING PERIKANAN MASYARAKAT KEDONGANAN MELALUI PELATIHAN PEMBUATAN ICE GEL
}

\author{
I.G.B.S. Dharma ${ }^{1}$, Y. Suteja ${ }^{2}$, I.G. Hendrawan ${ }^{3}$, I.G.N.P. Dirgayusa ${ }^{4}$, E. Faiqoh ${ }^{5}$ dan \\ Widiastuti ${ }^{6}$
}

\begin{abstract}
ABSTRAK
Salah satu wilayah pendaratan ikan hasil tangkapan di Selat Bali adalah Pantai Kedonganan. Masyarakat Kedonganan umumnya menggunakan es balok sebagai bahan pengawet karena murah dan mudah didapatkan, namun kekurangannya adalah cepat meleleh, sekali pakai, dan menghasilkan limbah cari saat meleleh. Salah satu solusi dari masalah ini adalah dengan ice gel yang bersifat dipakai berulang-ulang, tidak cepat cair dan tidak menimbulkan limbah saat mencair. Selain itu, ice gel dapat memberikan peluang usaha baru bagi masyarakat Kedonganan. Tujuan dari kegiatan ini adalah memberikan pelatihan cara pembuatan ice gel dan memberikan gambaran prospek pengembangan usaha ice gel. Metode yang digunakan adalah ceramah, praktek, dan diskusi. Masyarakat yang diundang adalah kelompok nelayan se Kelurahan Kedonganan, Pengusaha Cafe, Pedagang Ikan, ibu-ibu PKK dan stakeholeder kelautan perikanan. Kegiatan peningkatan daya saing perikanan masyarakat kedongan melalui pelatihan pembuatan ice gel berlangsung sangat baik dan berhasil yaitu memberikan tambahan pengetahuan bagi masyarat tentang ice gel secara umum, perbandingannya dengan es konvensial, cara pembuatan dan peluang usaha yang bisa dilakukan. Hasil pengabdian menunjukkan bahwa masyarakat memberikan respon positif berupa banyaknya pertanyaan yang diajukan dan akan diadakan inisiasi kerjasama lebih lanjut berupa pendampingan dan pelatihan.
\end{abstract}

Kata Kunci : Kedonganan, Perikanan, Pelatihan, Ice gel

\begin{abstract}
One of the fishing landing areas in the Bali Strait is Kedonganan Beach. Fisherman in Kedonganan use ice block as a preservative because they are cheap and easy to get, but the disadvantages are melting quickly, disposable, and producing waste when melting. One solution to this problem is with ice gel that is used repeatedly, much cooler and clean when melting. In addition, ice gel can provide new business opportunities for Kedonganan community. The purpose of this activity was to provide training on how to make ice gel and give an idea of new business development prospect. The methods used are lectures, practices, and discussions. The people invited are fishermen group of Kedonganan village, Cafe owner, Fish Traders, PKK women and marine fishery stakeholders. Increasing the competitiveness of the fishery community through the training of ice gel production is very good and succeeded in providing additional knowledge for the community about ice gel in general, the comparison with conventional ice, making ice gel and business
\end{abstract}

\footnotetext{
${ }^{1}$ Staf PengajarJurusan Ilmu Kelautan Fakultas Kelautan dan Perikanan Universitas Udayana,siladharma@unud.ac.id ${ }^{2}$ Staf PengajarJurusan Ilmu Kelautan Fakultas Kelautan dan Perikanan Universitas Udayana, yuliantosuteja@unud.ac.id

${ }^{3}$ Staf PengajarJurusan Ilmu Kelautan Fakultas Kelautan dan Perikanan Universitas Udayana, hendra_mil@yahoo.com ${ }^{4}$ Staf PengajarJurusan Ilmu Kelautan Fakultas Kelautan dan Perikanan Universitas Udayana, ignpdirgayusa@gmail.com

${ }^{5}$ Staf PengajarJurusan Ilmu Kelautan Fakultas Kelautan dan Perikanan Universitas Udayana, elok.widodo@gmail.com

${ }^{6}$ Staf PengajarJurusan Ilmu Kelautan Fakultas Kelautan dan Perikanan Universitas Udayana, widiastutikarim@unud.ac.id
} 
opportunity. The result of the training shows that the community gives positive response in the form of the number of questions asked and will be initiated further cooperation in the form of mentoring and training.

Keywords : Kedonganan, Fisheries, Training, ice gel.

\section{PENDAHULUAN}

Selat bali merupakan daerah yang memiliki potensi tangkapan ikan yang sangat tinggi. Ribuan ton sumberdaya ikan ditangkap oleh nelayan dalam setiap bulan. Menurut Ridha et al. (2013) tangkapan ikan nelayan akan semakin meningkat terutama pada saat musim pancaroba II dan musim barat (September - Februari). Salah satu wilayah pendaratan ikan hasil tangkapan di Selat Bali adalah Pantai Kedonganan. Kondisi wilayah yang dilengkapi dengan aksesibilitas yang bagus, fasilitas Pelabuhan pendaratan Ikan (PPI) dan adanya pasar ikan higienis membuat wilayah kedonganan sangat strategis.

Untuk mempertahankan kualitas ikan tangkapan agar tetap segar, masyarakat di Kedonganan umumnya menggunakan es balok sebagai bahan pengawet. Es ini digunaakan saat penyimpanan ikan di kapal, transportasi ikan di darat, pemasaran, bahkan sampai ikan dibawa oleh konsumen untuk di olah. Es dipilih sebagai bahan pengawet karena selain murah, pembuatan es juga tidak terlalu susah dan mudah didapatkan. Namun, es balok yang umumnya dibuat dan diperjualbelikan di pasar memiliki kekurangan yaitu es cepat meleleh, bersifat sekali pakai (langsung habis), dan menghasilkan limbah cari saat meleleh. Padahal jika es habis atau terlalu cepat meleleh, maka akan sangat menurunkan tingkat kesegaran ikan yang akan dijual atau dikonsumsi sehingga akan berdampak pada penurunan daya jual atau harga ikan.

Seiring dengan kemajuan pengetahuan, sekarang ini banyak pengusaha di sektor industri yang mulai beralih mengggunakan ice gel sebagai bahan pengawet. Menurut Sun (2006) kelebihan ice gel adalah bisa dipakai berulang-ulang, tidak cepat meleleh atau cair dan saat meleleh tidak menimbulkan limbah karena umumnya dikemas dalam wadah tertutup. Selain itu menurut Nurkusumaprama et al. (2014) ice gel mampu mengasilkan suhu $15^{\circ} \mathrm{C}$ selama 2 jam jika ditempatkan dalam styrofoam. Namun dengan semua keunggulan ini, harga ice gel tergolong mahal. Untuk ukuran 14 X 25 X 1,5 cm harganya bisa mencapai Rp. 70.000. harga Ini sangat mahal, apalagi jika digunakan oleh masyarakat nelayan. Padahal jika masyarakat Kedonganan membuatnya sendiri, harga ice gel jauh lebih murah dan memiliki kualitas hampir sama dengan yang dijual di pasaran. Penggunaan ice gel oleh masayarakat diharapkan mampu mepertahankan kesegaran ikan lebih lama sehinga daya jual ikan menjadi tinggi dan mampu meningkatkan keserjahtraan masyarakat. Selain untuk kebutuhan sendiri, pembuatan ice gel ini juga mampu memberikan peluang usaha masyarakat Kedonganan, mengingat wilayah Kedonganan memiliki pangsa pasar yang bagus dan kebutuhan es yang tinggi. Hal ini tentunya dapat meningkatkan pendapatan bagi masyarakat Kedonganan.

Berdasarkan analisis situasi masyarakat kedonganan di atas dapat dirumuskan masalah bahwa masyarakat di wilayah Kedonganan belum banyak mengetahui cara pembuatan ice gel yang murah dengan kuliatas yang hampir sama dengan dipasaran. Tujuan dari kegiatan pengabdian ini adalah Memberikan pelatihan kepada masyarakat kedonganan tentang cara pembuatan ice gel yang murah dan memiliki kualitas yang tinggi dan Membantu memberikan prospek pengembangan usaha ice gel mandiri bagi masyarakat kedonganan. 


\section{METODE PELAKSANAAN}

Kegiatan pengabdian berupa pelatihan pembuatan ice untuk meningkatkan daya saing perikanan masyarakat kedonganan melibatkan masyrakat umum, pedagang, nelayan dan kelompok nelayan yang secara langsung ataupun tidak langsung ada diwilayah Kedongan. Metode yang dipergunakan untuk menyelsaikan masalah yang ditemukan di lapangan adalah dengan memberikan materi presentasi secara oral tentang pembuatan ice gel dan prosepek usahanya, melakukan praktek pembuatan ice gel yang murah dan berkualitas tinggi, dan diskusi beserta tanya jawab dalam bentuk Focus Group Discusstion (FGD).

\section{HASIL DAN PEMBAHASAN}

Kegiatan Pengabdian kepada Masyarakat dengan judul "Peningkatan Daya Saing Perikanan Masyarakat Kedonganan Melalui Pelatihan Pembuatan Ice Gel" Kegiatan pengabdian ini mengalami beberapa perbahan terutama terkait masalah lokasi pelaksanaan. Pada awalnya kegiatan ini direncanakan pada balai banjar atau di kelompok nelayan, namun karena dukungan pihak kelurahan, kegiatan pengabdian ini kemudian dilaksanakan di Balai Kelurahan Kedonganan. Masyarakat yang diundang adalah kelompok nelayan se Kelurahan Kedonganan, Pengusaha Cafe, Pedagang Ikan, ibu-ibu PKK Kelurahan Kedonganan dan stakeholeder kelautan perikanan.

Kegiatan pengabdian ini dilaksanakan pada hari Senin tanggal 16 Oktober 2017 dari jam 9.3012.00 WITA. Peserta mulai melakukan registrasi dari pukul 9.30-10.00. Kegiatan pengabdian secara resmi dibuka oleh Lurah Kedonganan (Gambar 3.1). Lurah Kedonganan sangat mengapresiasi kegiatan pengabdian ini karena bisa membuka peluang usaha teruatama bagi ibu-ibu PKK dan ibu nelayan.

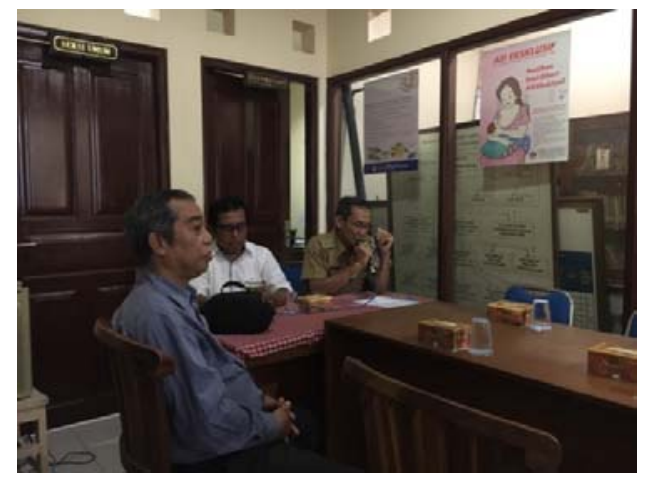

Gambar 3.1. Pembukaan kegiatan pengabdian oleh Lurah Kedonganan

Kegiatan pengabdian dilakukan dengan pemaparan materi tentang Ice Gel, keunggulan ice gel dibandingkan es konvensional, perhitungan ekonomi antara es konvensional (es balok) dengan ice gel, dan cara pembuatan (Gambar 3.2). Untuk meningkatkan pemahaman peserta pengabdian, pada saat pemaparan materi preseter memberikan beberapa sampel ice gel yang dijual di pasaran. Pada sesi pemaparan materi ini juga diberikan gambaran usaha yang bisa dilakukan oleh nelayan untuk mendapatkan penghasilan tambahan dari usaha ice gel. Gambaran usaha yang diberikan memberikan daya tarik tersendiri bagi peserta yang hadir. Masyarakat pada umumnya menganggap bahwa pembuatan ice gel sangat sulit dan susah dalam hal pemasaran. Namun setelah dilakukan pelatihan, masyarakat menyadari bahwa tehnik pembuatan ice gel sangat mudah dan membutuhkan biaya yang rendah namun memiliki nilai ekonomis yang tinggi. Respon positif terhadap prospek usaha ice gel ini akan ditindak lanjuti nantinya dalam kerjasama dengan pihak Lembaga 
Pemberdayaan Masyarakat (LPM) dan kelompok nelayan Kelurahanan Kedonganan. Kerjasama yang akan diinisiasi dibuat berupa program pendampingan dan pelatihan pembuatan ice gel dengan skala yang lebih besar.

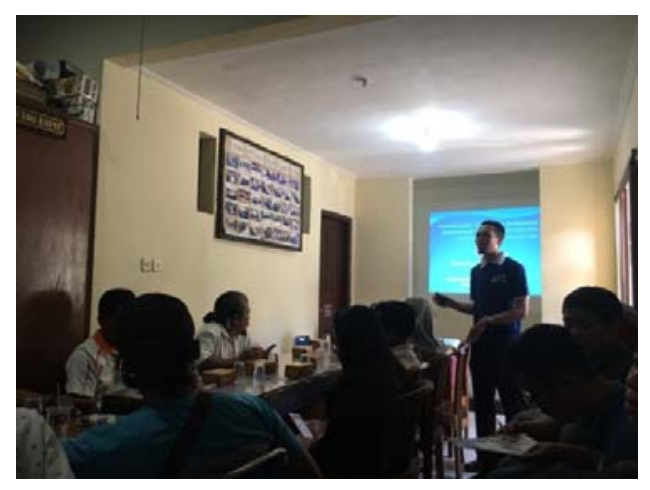

Gambar 3.2. Pemaparan materi oleh narasumber

Setelah pemaparan materi, team pengabdian dari fakultas kelautan dan perikanan melakukan demo cara pembuatan ice gel (Gambar 3.3) dengan menggunakan air, garam, tepung kanji dan kanji sebagai bahan utama. Proses pembuatan ice gel berlangsung dengan sangat baik dan memberikan daya tarik yang besar terhadap peserta. Hal ini terbukti dengan peserta pengabdian yang meperhatikan secara seksama tentang pembuatan ice gel dan banyaknya pertanyaan dari peserta terkait tehnik pembuatan. Kegiatan diskusi dilakukan secara interaktif dengan peserta pengabdian, dimana masyarakat dipersilahkan langsung menanyakan tentang hal-hal yang ingin diketahui seputar ice gel baik pada saat pemaparan materi maupun saat demo pembuatan. Masyarakat sebagian besar menanyakan tentang komposisi yang tepat dalam pembuatan ice gel, bagaimana perbandingan daya tahan antara es konvensional dengan ice gel dan tentang mekanisme pemaparan. Pelatihan pembuatan ice gel ini, selain tidak hanya diperagakan oleh nara sumber, namun dengan melibatkan partisipasi aktif dari masyarakat terutama mulai dari periapan alat sampai proses pengepakan ice gel.

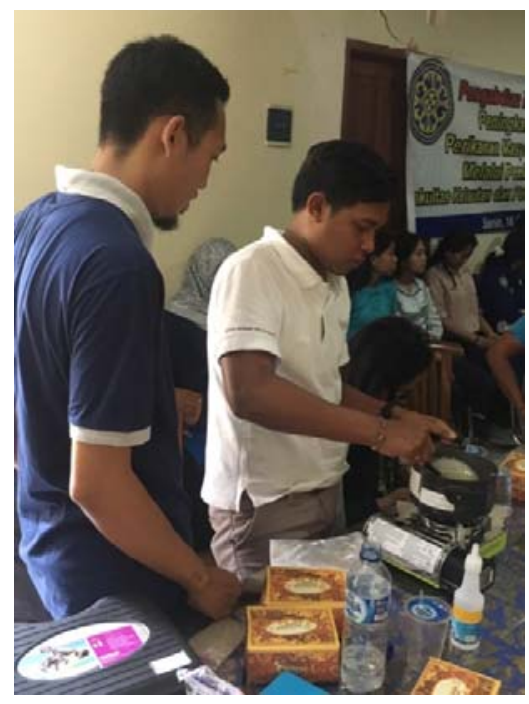

Gambar 3.3. Demo pembuatan ice gel 


\section{KESIMPULAN DAN SARAN}

Kegiatan peningkatan daya saing perikanan masyarakat kedongan melalui pelatihan pembuatan ice gel berlanngsung sangat baik dan berhasil yaitu memberikan tambahan pengetahuan bagi masyarat tentang ice gel secara umum, perbandingannya dengan es konvensial, cara pembuatan dan peluang usaha yang bisa dilakukan. Hasil pengabdian berupa pelatihan menunjukkan bahwa masyarakat memberikan respon positif berupa banyaknya pertanyaan yang diajukan dan akan diadakan inisiasi kerjasama lebih lanjut berupa pendampingan dan pelatihan.

Dari pelaksanaan kegiata pengabdian disarankan bahwa perlu difikirkan desain kemasan yang bagus dalam proses pengepakan ice gel sehingga dapat meningkatakan daya tarik masyarakat.

\section{UCAPAN TERIMAKASIH}

Penulis mengucapkan terima kasih yan sebesarnya-besarnya kepada universitas udayana yang telah membiaya pengabdian ini melalui skim Hibah Udayana Mengabdi tahun 2017. Penulis juga mengucapkan terima kasih yang sebesar-besarnya kepada masyarakat kedonganan, kelurahan kedonganan, mahasiswa, dan pihak-pihak yang membantu dalam kelancaran kegiatan pengabdian ini.

\section{DAFTAR PUSTAKA}

Nurkusumaprama, A., E. Darmawati, Y.A. Purwanto (2014). Aplikasi Ice Gel pada Kemasan untuk Transportasi dan Penyimpanan Sementara Jamur Tiram (Pleurotus ostreatus). Jurnal Keteknikan Pertanian Vol 2: 2, pp. 141-148

Ridha, U., M.R. Muskananfola, A. Hartoko (2013). Analisa Sebaran Tangkapan Ikan Lemuru (Sardinella Lemuru) Berdasarkan Data Satelit Suhu Permukaan Laut dan Klorofil-A di Perairan Selat Bali. Diponogoro Journal of Maquarest. Vol 2: 4, pp. 53-61.

Sun, DW (2006), Handbook Of Frozen food processing and packaging, Taylor and Francis Group, United State of America. 